\title{
Variations in some Nutritional Status Indicators among Students in the University of Colombo
}

Rose G. X. PeIRIS,

University of Colombo, Colombo 3, Sil Lanka

Dultitha N. Fernando

Department of Conmunity Medicine, Faculty of Medicine, Kynsey Road, Colombo 8, Sri Lanka

AND

K. ABeywickrama

Temple Road, Colombo 10, Siri Lanka

(Date of receipt: 17 February 1984)

(Date of acceptance: 30 March 1984)

\begin{abstract}
Data related to socio-economic status and some indicators of nutritional status were obtained from 769 students who gained admission to the four faculties in the University of Colombo in 1981. The nutritional status indicators studied were height, weight, weight for height, haemoglobin concentration and age at menarche. Students from different faculties differed markedly in their socio-economic background, as well as in their nutritional status. The students from the Faculty of Medicine, a larger proportion of whom were from higher socio-economic groupings had better anthroponetric parameters, lower prevalence of anaemia and a lower mean age at menarche compared to the students from the other faculties, the worse affected being students from the Faculty of Arts. The high prevalence of anaemia observed among this apparently healthy young adults was of special significance.
\end{abstract}

\section{Introduction}

In Sri Lanka, students from varied socio-economic backgrounds gain entry to the University, due to the free education policy adopted by successive governments. University students occupy an important position in a society, being the group from which the future intelligentsia of the country emerge.

The earliest information on the health and nutritional status of the university students is available from the study by Bibile et al ${ }^{2}$, according to which tropical parasitic disorders $(48 \%)$ and malnutrition $(17 \%)$ dominated the clinical picture. Wickramanayake ${ }^{10}$ in his study on university students who were resident in the hostels, observed that the calorie intake among the male students were below the 'recommended allowance' whereas for the females, the intake was higher.

Recent surveys on nutritional status carried out in Sri Lanka have identilied the prevalence of protein calorie malnutrition among pre-school children and school children to be considerably high.7,8 
Information related to some nutritional status indicators among an important young adult population such as university students would be most useful. This study was planned to obtain such data with a view to identifying the socio-economic characteristics infuencing these indicators.

\section{Methodology}

The study population were the students who entered the University of Colombo in 1981 (769). They entered the four Faculties of Medicine (189), Science (141) Law (66) and Arts (373). The nutritional status indicators that were identified for purposes of this study had to be limited to those that are practicable with minimum resources i.e. measurements of height and weight, assessment of haemoglobin level. Assessment of the age at menarche was also carried out, as this is considered as a population indicator of nutritional status. ${ }^{1}$

Personal and socio-economic information related to each student was obtained by using an interviewer administeree questionnaire which was pre-coded. Two nursing sisters at the Health Centre, University of Colombo were trained in administering the questionnaire. Reliability checks were done by one of the authors (RGXP). Age at menarche was also obtained during the interview.

Anthropometric measurements carried out were height and weight. Height was measured in centimetres using a sliding scale calibrated vertically and recordings were made to the nearest $0.1 \mathrm{~cm}$. All students were weighed wearing light clothing without shoes, using a platform beam balance. Weight was recorded to the nearest $0.1 \mathrm{~kg}$. Two trained investigators were responsible for making all the measurements. Instruments were standardised at regular intervals. One of the authors (RGXP) was responsible for repeating the measurements on a random sample of the study population.

Haemoglobin estimation was done by the oxyhaemoglobin method using a photoelectric colorimeter, for which blood samples were obtained from the students.

\section{Results}

All 769 students who entered the four faculties in the University of Colombo were included in the study. There were no refusals. The study population comprised of $50.8 \%$ males and $40.2 \%$ females and their mean ages were 22.6 years and 22.06 years respectively. The subjects were divided according to the 'faculty' to which they gained entry. This sub-division into 4 groups has been used for comparison of the identified indicators as it has been observed that the socio-economic backgrounds of students differ among the faculties. 
Two criteria were adopted to assess the socio-economic status of the study population, i.e. monthly income of the family and occupation of head of the family. Distribution of family income per month among students showed well marked inter-faculty differences (Table 1).

TABLE 1. Distribution of study population by family income

\begin{tabular}{lrrrrrr}
\hline \multicolumn{1}{c}{ Faculty } & \multicolumn{7}{c}{ Family income in Rs. per month } \\
\hline Medicine & 300 & $301-500$ & $501-1000$ & $1001-1500$ & 1500 & Total \\
Science & 10 & 15 & 34 & 60 & 70 & 189 \\
Law & 9 & 16 & 34 & 24 & 57 & 140 \\
Arts & 27 & 11 & 7 & 4 & 17 & 66 \\
All Faculties & 228 & 72 & 52 & 16 & 5 & 373 \\
& 274 & 114 & 127 & 104 & 149 & 768 \\
\hline
\end{tabular}

No information - 1

Two income categories 'high' and 'low' were identified. Low income was defined as a total family income of Rs 1000 and less per month and 'high' income as more than Rs. 1001 per month. On considering the total study population, $67 \%$ belonged to the 'low' income group. It is observed that the proportion of students belonging to the 'low' income group was as high as $94 \%$ among the students from the Faculty of Arts compared to $31.2 \%$ among those in the Faculty of Medicine (Table 2).

TABLE 2. Income distribution by faculty

\begin{tabular}{|c|c|c|c|}
\hline \multirow[b]{2}{*}{ Faculty } & \multicolumn{3}{|c|}{$\%$ within the income group } \\
\hline & Low & High & Total \\
\hline Medicine & 31.2 & 68.8 & $100 \%$ \\
\hline Science & 42.1 & 57.8 & $99.9 \%$ \\
\hline Law & 68.2 & 31.8 & $100 \%$ \\
\hline Arts & 94.4 & 5.6 & $100 \%$ \\
\hline All Faculties & $67 \%$ & $33 \%$ & $100 \%$ \\
\hline
\end{tabular}

On application of sinnificance tests, highly significant differences (18 standard deviations) from the media were obtained when tested against the alternative that income decreases as one proceeds in the order of faculties - Medicine, Science, 
Law and Arts. The level of significance is too high and leads to the suspicion that the lowest incomes were underestimates, perhaps to qualify for student loans and bursaries.

Social class was determined according to the occupation of the head of the family, which was classified into one of the following five categories:-

i. Professional

ii. Executives, Managers, etc.

iii. Skilled employment

iv. Semi-skilled workers

v. Unemployed.

In order to make a clearer distinction among "social classes" thus identified, categories I and II were combined to form Group I and categories III, IV \& V were combined to form Group II. A marked inter-faculty difference is observed as shown in Table 3 .

TABLE 3. Social class distribution by faculty

\begin{tabular}{|c|c|c|c|c|c|c|}
\hline Faculty & No. & $\underbrace{}_{\%}{ }^{S o}$ & $\begin{array}{l}\text { lass } \\
\text { Gr } \\
\text { No. }\end{array}$ & & \multicolumn{2}{|c|}{ Total } \\
\hline Medicine & 143 & $75.6 \%$ & 46 & $24.3 \%$ & 189 & $100 \%$ \\
\hline Science & 34 & $24.1 \%$ & 107 & $75.8 \%$ & 141 & $100 \%$ \\
\hline Law & 13 & $19.1 \%$ & 53 & $80.3 \%$ & 66 & $100 \%$ \\
\hline Arts & 12 & $3.2 \%$ & 361 & $96.8 \%$ & 373 & $100 \%$ \\
\hline All Faculties & 202 & $26.3 \%$ & 567 & $73.7 \%$ & 769 & $100 \%$ \\
\hline
\end{tabular}

$75.6 \%$ of medical students belonged to Group I, the comparable figure for arts students being $3.2 \%$. The difference observed was highly significant showing that the proportion of professionals and executives as head of the family decreased as one proceeds in the order of faculties - Medicine, Science, Law and Arts.

Average weight and height values of the study population are given in Table 4, according to the faculties and for the sexes separately. 
TABLE 4. Mcan height and weight of the study population according to faculties (Sexes separate)

\begin{tabular}{|c|c|c|c|c|c|c|}
\hline Faculty & Sex & Number & $\begin{array}{l}\text { Height in } \\
\text { Mean } \%\end{array}$ & s. $S . D$. & $\begin{array}{l}\text { Weight in } \mathrm{Kg} \\
\text { Mean } \%\end{array}$ & $S . D$. \\
\hline \multirow[t]{2}{*}{ Medicine } & M & 98 & 168.4 & 6.6 & 51.8 & 6.9 \\
\hline & $\mathrm{F}$ & 91 & 157.8 & 5.3 & 44.03 & 5.6 \\
\hline \multirow[t]{2}{*}{ Science } & $M$ & 87 & 166.9 & 5.0 & 50.69 & 7.1 \\
\hline & $\mathrm{F}$ & 54 & 154.5 & 5.8 & 42.9 & 5.8 \\
\hline \multirow[t]{2}{*}{ Law } & $M$ & 36 & 164.4 & 5.2 & 42.9 & 5.4 \\
\hline & $\mathrm{F}$ & 30 & 155.4 & 6.2 & 44.4 & 4.7 \\
\hline \multirow[t]{2}{*}{ Arts } & $M$ & 170 & 163.8 & 5.8 & 49.01 & 6.0 \\
\hline & $\mathrm{F}$ & 203 & 152.7 & 5.4 & 42.8 & 5.5 \\
\hline
\end{tabular}

For males, there was a significant difference for mean height and for mean weight between medical and arts students using tests for multiple comparisons $(\mathrm{p}<0.01)$ by both the Tukey and the Bonferroni methods (medical greater than arts). Among females, the difference was significant in respect of height $(\mathrm{p}<0.01)$ but not for weight.

In an adult population, assessment of nutritional status based on height or weight alone may not be adequate and indices based on weight/height ratios have been used. ${ }^{\sigma}$ Weight as a percentage of standard weight for his/her height was calculated for each student and comparisons were made with the weight for height data given in the ICNND tables of USA." (There are no reference tables for anthropometric data for adults in Sri Lanka).

The study population was divided into 5 groups according to their percentage deviation from the weight/height standard, i.e. ICNND tables. In these tables $100 \%$ was the "ideal" weight for a given height for American adults and it was observed that very high proportion of the study population were shorter and lighter than the Americans, hence it was decided to adopt the following classification--

Group J- Students below $70 \%$ of the weight for height

" II- Students below $70.74 \%$ of the weight for height

" III- Students below $75-79 \%$ of the weight for height

" IV- Students below $80-84 \%$ of the weight for height

"V- Students below more than $84 \%$ of the weight for height

Tables 5 and 6 shows the distribution of the study population by the 'nutritional group' (sexes separately). 


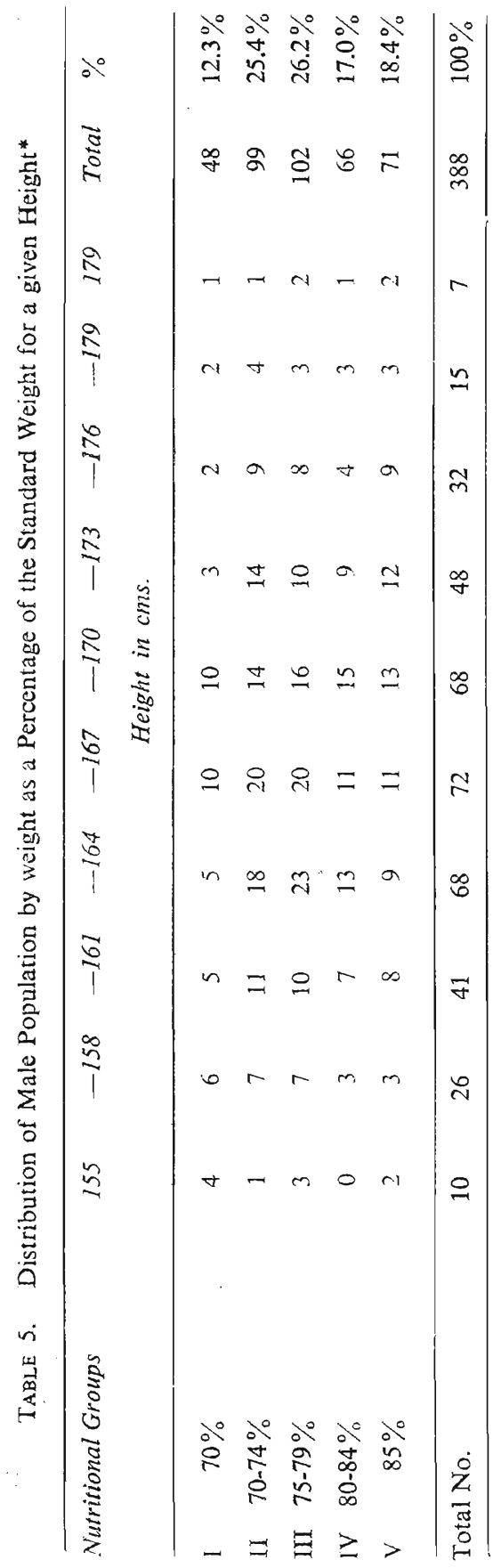




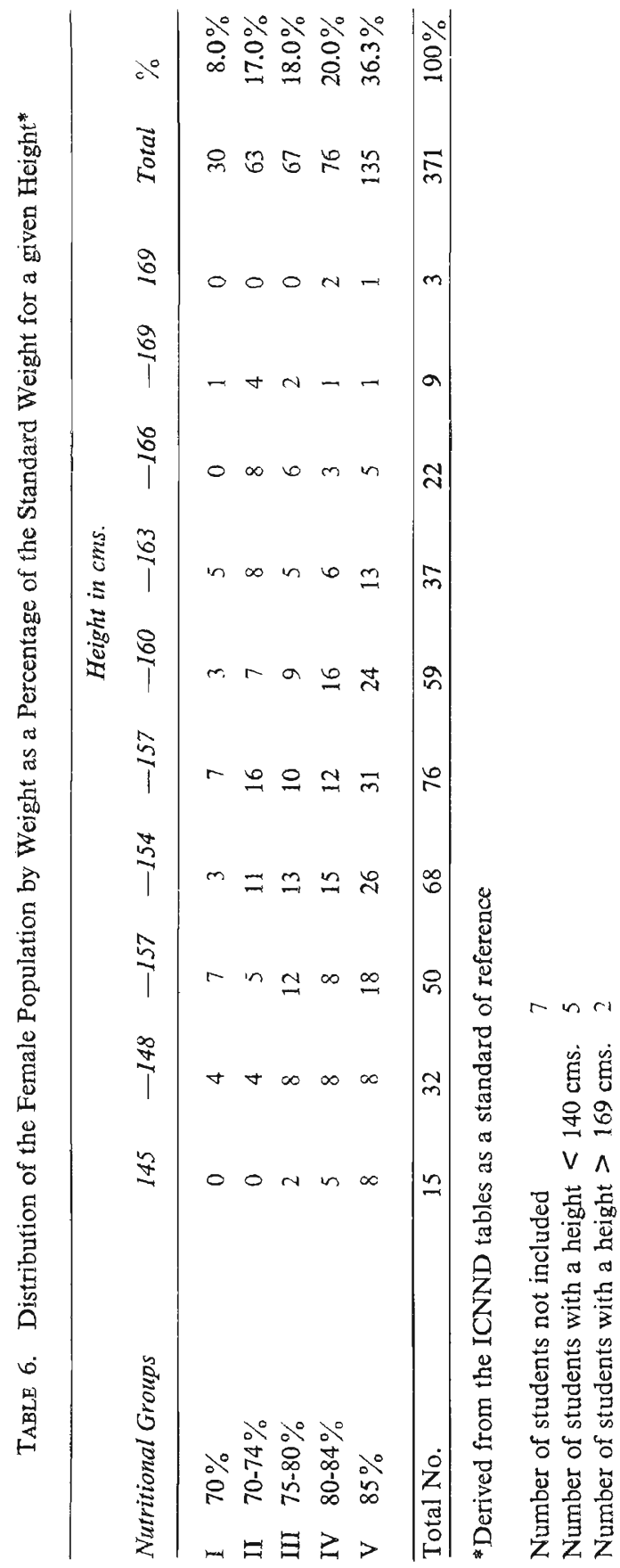


The pattern observed was different for the two sexes. The proportion of male students in Group V $(18.4 \%$ ) is lower than that of females $(36.3 \%)$. Among the females, there was a shift of the table to the left and downwards compared to the males. The shift to the left imply that the Sri Lankan females studied are shorter than the American female by a larger amount than the male. The shift downwards implies that even though the females are 'short' in stature, for a majority of them their weight in relation to their height was $84 \%$ or more when compared with the reference values. It was also observed that the proportion of males who were of 'short stature' and belonged to Group V were lower, compared to the females.

Tables 7 and 8 show that there was no significant inter-faculty difference observed in the proportion of students belonging to the different nutritional groups, (using Chi-square based on ordered groups, Lehman, ${ }^{6}$ ).

TABLE 7. Number of Students in each Nutritional Group by Faculty - (Males)

\begin{tabular}{|c|c|c|c|c|c|c|c|c|c|}
\hline $\begin{array}{l}\text { Nutritional } \\
\text { Group }\end{array}$ & $\mathrm{Mec}$ & dicine & & $\begin{array}{l}\text { Faculty } \\
\text { Science }\end{array}$ & & Law & & Arts & $\begin{array}{l}\text { All } \\
\text { Faculties }\end{array}$ \\
\hline 1 & 13 & $13.3 \%$ & 13 & $14.9 \%$ & 5 & $13.9 \%$ & 17 & $10.0 \%$ & 48 \\
\hline 2 & 18 & $18.4 \%$ & 24 & $27.6 \%$ & 10 & $27.7 \%$ & 46 & $27.0 \%$ & 98 \\
\hline 3 & 28 & $28.6 \%$ & 21 & $24.1 \%$ & 5 & $13.9 \%$ & 49 & $28.8 \%$ & 103 \\
\hline 4 & 20 & $20.4 \%$ & 8 & $9.2 \%$ & 10 & $27.7 \%$ & 28 & $16.5 \%$ & 66 \\
\hline 5 & 19 & $14.4 \%$ & 21 & $24.1 \%$ & 6 & $16.6 \%$ & 30 & $17.6 \%$ & 76 \\
\hline Total & 98 & $100 \%$ & 87 & $100 \%$ & 36 & $100 \%$ & 170 & $100 \%$ & 391 \\
\hline
\end{tabular}

TABLE 8. Number of Students in each Nutritional Group by Faculty -... (Females)

\begin{tabular}{|c|c|c|c|c|c|c|c|c|c|}
\hline $\begin{array}{l}\text { Nutritional } \\
\text { Group }\end{array}$ & $\mathrm{Me}$ & dicine & & $\begin{array}{l}\text { Faculty } \\
\text { Science }\end{array}$ & & Lav & & Arts & $\begin{array}{l}\text { All } \\
\text { Faculties }\end{array}$ \\
\hline 1 & 8 & $8.7 \%$ & 6 & $11.0 \%$ & 2 & $6.6 \%$ & 15 & $7.4 \%$ & 31 \\
\hline 2 & 20 & $22.0 \%$ & 9 & $16.6 \%$ & 2 & $6.6 \%$ & 32 & $15.7 \%$ & 63 \\
\hline 3 & 16 & $17.6 \%$ & 13 & $24.0 \%$ & 7 & $23.3 \%$ & 33 & $16.3 \%$ & 68 \\
\hline 4 & 23 & $25.3 \%$ & 7 & $12.9 \%$ & 6 & $20.0 \%$ & 40 & $19.7 \%$ & 76 \\
\hline 5 & 24 & $26.4 \%$ & 19 & $35.0 \%$ & 13 & $43.3 \%$ & 83 & $40.8 \%$ & 139 \\
\hline Total & 91 & $100 \%$ & 54 & $100 \%$ & 30 & $100 \%$ & 203 & $100 \%$ & 378 \\
\hline
\end{tabular}


On studying the distribution of students in different nutritional groups in relation to their income, it was observed that there was no significant difference among the male students. However, for the females, the highest proportion of students in the nutritional group V (i.e. weight for ht. $84 \%$ or more) belonged to the low income groups (Table 9 and 10).

TABLE 9. Number of students in each nutritional group by family income -... Males

\begin{tabular}{|c|c|c|c|c|c|c|}
\hline \multirow{2}{*}{$\begin{array}{l}\text { Nutritional } \\
\text { Group }\end{array}$} & \multicolumn{5}{|c|}{ Fanily income in Rs. per month } & \multirow{2}{*}{$\begin{array}{l}\text { All income } \\
\text { Groups }\end{array}$} \\
\hline & $<300$ & $301-500$ & $501-1000$ & $1001-1500$ & $>1500$ & \\
\hline 1 & 19 & 5 & 11 & 6 & 7 & 48 \\
\hline 2 & 40 & 13 & 18 & 13 & 15 & 99 \\
\hline 3 & 44 & 20 & 17 & 7 & 15 & 103 \\
\hline 4 & 24 & 9 & 17 & 9 & 7 & 66 \\
\hline 5 & 27 & 12 & 7 & 9 & 21 & 75 \\
\hline Total & 154 & 59 & 70 & 44 & 65 & 391 \\
\hline
\end{tabular}

TABLE 10. Number of students in each nutritional group by family income -... females

\begin{tabular}{|c|c|c|c|c|c|c|}
\hline \multirow{2}{*}{$\begin{array}{l}\text { Nutritional } \\
\text { Group }\end{array}$} & \multirow[b]{2}{*}{$<300$} & \multicolumn{4}{|c|}{ Family income in Rs. per month } & \multirow{2}{*}{$\begin{array}{c}\text { All income } \\
\text { Groups }\end{array}$} \\
\hline & & $301-500$ & $501-1000$ & $1001-1500$ & $>1500$ & \\
\hline 1 & 7 & 3 & 6 & 8 & 7 & 31 \\
\hline 2 & 13 & 9 & 13 & 11 & 17 & 63 \\
\hline 3 & 19 & 11 & 9 & 14 & 15 & 71 \\
\hline 4 & 22 & 9 & 14 & 13 & 18 & 76 \\
\hline 5 & 58 & 23 & 14 & 13 & 29 & 137 \\
\hline Total & 119 & 55 & 56 & 59 & 89 & 378 \\
\hline
\end{tabular}

$x^{2}-\ldots 10.726$ on $4 \mathrm{df} \quad \mathrm{p}<0.05$

Mean haemoglobin levels of the study population in different faculties is given in Table 2 (sexes separately). Within each faculty, the mean values for males is higher than that for females. However, between faculties, the highest values were observed for students in the Faculty of Medicine. 
TABre 11. Mean haemoglobin concentration by faculty (sexes separately)

\begin{tabular}{llllr}
\hline Faculty & Male & $S D$ & Female & $S D$ \\
\hline Medicine & 12.46 & 1.3 & 11.54 & .9 \\
Science & 11.97 & 1.2 & 10.35 & 1.1 \\
Law & 11.04 & 1.2 & 10.29 & 1.2 \\
Arts & 11.9 & 1.3 & 10.63 & 1.2 \\
\hline
\end{tabular}

Haemoglobin levels below which anaemia is said to exist is considered to be in the adult males $13 \mathrm{gm} \%$ and adult females (non-pregnant) $12 \mathrm{~g} \% .^{11}$ According to the above definition, the prevalence of anaemia among the two "income groups" was studied (Table 12). For males the prevalence of anaemia was significantly lower among the higher income group, whereas for the females the differenc: observed was not statistically significant.

TABle 12. Prevalence of anaemia in relation to family income

(a) Males

\begin{tabular}{lcr}
\hline $\begin{array}{l}\text { Family } \\
\text { income }\end{array}$ & $\begin{array}{l}\text { Number } \\
\text { anaemic }\end{array}$ & $\begin{array}{r}\text { Number } \\
\text { not anaemic }\end{array}$ \\
\hline Low & 167 & 46 \\
High & 114 & 64 \\
Total & 281 & 110 \\
\hline$x^{2}-9.89$ df -1 & & \\
$p>0.01$ & &
\end{tabular}

(b) Females

\begin{tabular}{lcc}
\hline $\begin{array}{l}\text { Family } \\
\text { income }\end{array}$ & $\begin{array}{l}\text { Number } \\
\text { anaemic }\end{array}$ & $\begin{array}{r}\text { Number } \\
\text { not anaemic }\end{array}$ \\
\hline & & \\
Low & 150 & 25 \\
High & 161 & 42 \\
Total & 311 & 67 \\
\hline
\end{tabular}

$x^{2}-2.64 \quad$ df -1

All females in the study population (378) had responded to the question on their age at menarche. The mean age at menarche was 13.3 years while it ranged from 11 to 19 years. $75.2 \%$ had attained menarche below 15 years of age. Interfaculty differences were observed in the mean age, with lowest values in respect of the girls at the Faculty of Medicine and highest in the Faculty of Arts (Table 13). 
TABLE 13. Mean age at Menarche in years - by faculty

\begin{tabular}{lcc}
\hline Faculty & Menarche in years & S.D. \\
\hline Medicine & 12.68 & 2.6 \\
Science & 12.6 & 3.0 \\
Law & 13.3 & 1.3 \\
Arts & 13.7 & 2.4 \\
All faculties & 13.3 & \\
\hline
\end{tabular}

TABLE 14. Age at Menarche and family income

\begin{tabular}{|c|c|c|c|c|c|}
\hline $\begin{array}{l}\text { Family income in } \\
\text { Rs. per month }\end{array}$ & \multicolumn{5}{|c|}{ Age at mienarche in years } \\
\hline $\begin{array}{l}<300 \\
301-500 \\
501-1000 \\
1001-1500 \\
1500>\end{array}$ & $\begin{array}{r}6 \\
6 \\
12 \\
16 \\
34\end{array}$ & $\begin{array}{l}19 \\
20 \\
20 \\
19 \\
24\end{array}$ & $\begin{array}{l}44 \\
15 \\
14 \\
15 \\
21\end{array}$ & $\begin{array}{r}51 \\
14 \\
11 \\
10 \\
7\end{array}$ & $\begin{array}{r}120 \\
55 \\
57 \\
60 \\
86\end{array}$ \\
\hline Total & 74 & 102 & 109 & 93 & 378 \\
\hline
\end{tabular}

TABLE: 15. Age at menarche and social class

\begin{tabular}{lccccc}
\hline Social Class & $<11$ & $11.1-12.5$ & \multicolumn{4}{c}{ Age at menarche in years } & $12.6-14$ & 14.1 \& above & Total \\
\hline 1 & 35 & 42 & 31 & 8 & 116 \\
2 & 39 & 60 & 78 & 85 & 262 \\
All classes & 74 & 102 & 109 & 93 & 378 \\
\hline
\end{tabular}

$x^{2}-34.7 \quad$ df $\cdots 3 \quad p<0.005$

Age at menarche was significantly related to the family income in that the age at menarche increases with decreasing family income.

On studying the pattern among the two social class groupings, it is observed that the daughters of 'professionals' and 'executives' attained menarche earlier than the others. 


\section{Discussion}

In Sri Lanka, University students are a highly selected group in the community, hence they are not representative of the entire young adult population in the country. There were marked socio-economic status differences between the students of different faculties which may be attributed to the criteria governing university entry and to differences in the educational facilities available islandwide, specially those for science education.

Medical students, the majority of whom belonged to higher socio-economic groupings had higher mean values in respect of some of the indices studied i.c. mean height, weight and haemoglobin level. Mean age at menarche was lower among the girls in the Medical Faculty compared to those from the Faculties of Law and Arts.

Observations on mean height and weight made in this study are higher than those made by Collumbine ${ }^{3}$ on Sri Lankan university students even though the majority of university students at that time belonged to higher socio-economic status. A factor that may be relevant in the increase observed in height from 1949 to 1981 may be the secular trends observed, where the national averages in heights are increasing worldwide. ${ }^{9}$

Many studies have shown that differences in physical stature can be attributed not only to differences in genetic make up but also to environmental factors, especially nutrition. Within a genetically similar population, if difierences were seen between sub-groups, then the importance of environmental factors become more relevant. As such, the significant inter-faculty differences observed in these parameters need to be related to the socio-economic differences among the students in the different faculties.

However, when weight:height relationship was studied the pattern observed was different, specially among the females. There were more 'arts' students who had higher weight height ratios than medical students. Therefore, on the average, the arts students may be stunted or short for age but their weight in relation to their height seems adequate. A possible explanation may be that this group of students who are from a lower socio-economic grouping may have suffered from chronic malnutrition in childhood resulting in short stature but subsequently improved their nutritional status, thus reaching a satisfactory weight:height ratio. This improvement may be due to a 'selection' of the particular student within the family, having been chosen for higher education, or to a general improvement throughout the country.

The detection of a high prevalence of anaemia in an apparently healthy university population is of importance, as it is known that even though the symptoms 
of anaemia are not overt except in severe forms of the disease, reduction in physical capacity and increased susceptibility to infection is associated with araemia.

The information on some nutritional status indicators available on this select group of young adults identifies the need to review the concept of "at risk" groups in directing nutritional programmes, with special consideration given to lower socio-economic groupings.

\section{Acknowledgements}

We wish to thank the Vice Chancellor, University of Colombo, for granting permission to carry out this study and for the financial assistance provided.

Staff of the Health Centres and the Statistical Unit of the University of Colombo extended their cooperation throughout this study. To them we are very grateful.

\section{References}

1. Beaton, G. H., \& Bengoa, J. M. (1976). Practical population indicators of health and mutrition, Nutrition in Preventive Medicine, Pg. 515, Who, Geneva.

2. Bibile, S. W., Collumbine, H., Warson, R. S. \& Wickramanayake T. (1949). The health of University students in the tropics, Ceylon J. Med. Sci. 6.

3. Collumbine, H. (1949). Ceylon J. Med. Sci. 6. Pg. 165.

4. JELIFFE, D. B. (1966). The Assessment of Nutritional status of the community, WHO Monograph Series No. 53, Pg. 63-94 WHO, Geneva.

5. Khosla, T. \& Lowe, C. R. (1967). Br. J. Prev. Soc. Med. 21. (3) p. 122-128.

6. Lehmann, E. L. (1975). Nonparametics: Statistical Methods based on Ranks, McGraw Hill.

7. Sri Lanka, CARE 1981, Sri Lanka Primary School Nutrition Survey, Colombo.

8. Sri Lanka Ministry of Plan Implementation Food and Nutrition Policy Planning Division. Nutritional Status, its determinants and intervention programmes Interior Report 1980, p $4-10$

9. Tanner J. M. \& Eveleth Phyllis, B. (1976). Worldwide variation in Human Growth. International Biological Programmes, Cambridge, Cambridge University Press. Pg. 212-264

10 Wickramanayake T. W (1962). Nutritional Status of medical students in Colombo, Student Health in Asia, WUS Asian Health Conference Report, Geneva, Pg. 52-53.

11. WHO Technical Series No. 503 (1972) Pg. 200, WHO, Geneva. 